\title{
Framing of Opposing Corporate and Activist NGO Website Communications: Impacts on Perceptions of Tripartite Sustainability Values and Joining Online Networks
}

\author{
Michèle Paulin ${ }^{1}$, Kaspar Schattke ${ }^{2}$, Ronald J. Ferguson ${ }^{1, *}$ \\ ${ }^{1}$ Department of Marketing, John Molson School of Business, Concordia University, Montreal, Canada \\ ${ }^{2}$ Département de psychologie, Université du Québec à Montréal, Canada \\ ${ }^{*}$ Corresponding Author: ronald.ferguson@concordia.ca
}

Copyright@2019 by authors, all rights reserved. Authors agree that this article remains permanently open access under the terms of the Creative Commons Attribution License 4.0 International License

\begin{abstract}
This research investigated the impacts of the diverse framings of corporate and activist NGOs website communications of a proposed Canadian oil-sands pipeline on participants' perceptions of a) the tripartite sustainability values of environmental safety, economic benefits and community social relations and b) the willingness to join the corporate and activist NGOs online networks. Given the importance of sustainability issues in business education curricula and research, the participants were drawn from a population of undergraduate students. They were exposed online to either neutral information (control group), or randomly exposed initially to either the Corporate or Activist NGOs website communications. These exposures were subsequently reversed creating a combined group exposed to both agenda framings. Results demonstrated the persuasive power of both communication framings. The Corporate communication created positive perceptions of tripartite sustainability values, whereas the Activist NGOs' created negative perceptions. After exposures to the opposite communications, the Corporate group's perceptions changed from positive to negative, whereas the Activist NGOs perceptions only became somewhat less negative. Also there was a stronger willingness to join an Activist NGO rather than the corporate online action network. The empirical findings reflect the powerful diverse impacts of agenda framing on a highly controversial societal issue. Concerned citizens, researchers, politicians and academics should not restrict their website consultation to just one framing of such complex wicked issues. The present findings also have important implications for developing a more balanced and ethical business curriculum in the area of sustainability and common good.
\end{abstract}

Keywords Tripartite Sustainability Values, Oil Sands Pipelines, Wicked Social Issues, Website Agenda Framing

\section{Introduction}

Corporate sustainability has developed over the past two decades into a legitimate sub-field of sustainability research for management and organization scholars (Hahn, Figge, Aragon-Correa \& Sharma, 2017). Dyllic and Muff (2016) view the concept of corporate sustainability as having evolved from Elkington's (1994) Triple Bottom Line (TBL) accounting approach to one requiring thinking and acting from outside-in strategies creating triple "values for the common good" rather than inside-out initiatives. Corporate sustainability, TBL and Corporate Social Responsibility (CSR) are closely related concepts, each proposing that companies should integrate economic, social and environmental impacts into their strategies and communication (Alves, 2009). Communication research in sustainability science can investigate how diverse message framing of controversial issues can influence how people come to perceive and respond to these tripartite values of environmental, social, and economic sustainability (Smith, Suldovsky, and Lindenfeld (2016).

Website communications have become both the "public face" of an organization and the vehicle through which intense and meaningful interactions can take place (Lovejoy and Saxton, 2012). Corporate websites are powerful visual communication tools to enhance a company's image and counteract activist critiques (Kassinis and Panayiotou, 2017). Issues management was originally a distinct business process whereby a firm sought to shape public policy decisions by the power to; influence, persuade and motivate (Coombs and Holladay, 2018; Jaques, 2006). However, website communications employed in issues management by corporations and 
activist NGOs have become virtually indistinguishable (Gauthier and Kappen, 2016). Although this is sometimes effective in reaching mutual agreements, it often results in extreme diverse positions on controversial issues involving "wicked problems". Coombs and Holladay (2018) citing Termeer et al. (2013) describe these problems as difficult to resolve, ambiguous, contentious and socially complex. Most often targets of activist NGOs are oil and utilities companies. They have been described as so-called "dirty" industries and are more likely to be labelled as "greenwashers" (Cherry and Sneirson, 2012; Lyon and Montgomery, 2013). This conflict arena poses several pro-versus-con wicked communication issues. It is characterized as a wide-ranging PR "virtual war" with the creative use of the internet, digital technologies and social media deployed by combatants of the fossil fuel industry and by dissident NGO activist and protest groups (McQueen, 2015).

The present empirical research investigates the impacts of the contradictory framing of corporate and activist NGOs website communications regarding the issue of a proposed project in the above-mentioned category of "dirty" industries. It compares the impacts of both corporate (TransCanada Ltd.) and activist NGOs (e.g. Council of Canadians) website communications regarding perceptions of the impacts of the proposed Energy East Pipeline Project in Canada. These pro-versus-con website communications of the controversial issue of bituminous pipelines was chosen because it was the most newsworthy Canadian Press business story of the year 2016. This $4600 \mathrm{~km}$ pipeline would transport diluted bitumen from the Alberta oil (tar) sands to New Brunswick on the Atlantic coast. It is one of three other proposed similar pipelines: TransCanada Ltd Keystone XL to join the existing Keystone Pipeline through the Nebraska in the United States to the Gulf Coast and the Kinder Morgan and Northern Gateway Pipelines to British Columbia and the Pacific Coast.

\subsection{The Empirical Study}

The general purpose of this research was to investigate the comparative impact of this website battle on the perceptions of the tripartite sustainability values of the proposed Energy East Pipeline. Similar to Eagle et al.
(2015), we investigated sustainability perceptions of new entrants to a business school. These Millennial students are particularly pertinent for this study given that they are digitally savvy, have a vested interested in the longer-term impacts of sustainable corporate practices and will be future leaders of for- and not-for-profit organizations. Studying this population's perceptions of corporate sustainability values is also relevant given that the majority of sustainability policies treated in higher education in Canada are based on the triple pillars of sustainability (Vaughert et al., 2016). In their treatment of education for sustainable development, Kagawa (2007) point out that university student perceptions of sustainable development have been under researched. They also point out that student acceptance of sustainability is useful only if it is accompanied by an understanding of its contested meanings.

Therefore, the specific purposes of this research were to study the impacts of these contradictory pro-versus-con website communications on first-year business school students' perceptions of a) the sustainability values of environmental safety, economic benefits and community social relations regarding the proposed Energy East Pipeline and, b) their subsequent willingness to join the corporate and activist NGOs online action networks about this pipeline. The study addresses the concerns of Delmas and Aragon-Correa (2016) who point out the need for more empirical investigations of corporate sustainability through the design of studies with voluntary participation in control and randomized unbiased treatment groups (See Research design, Figure 1). As such, one experimental group was first exposed to the Corporate and subsequently to the NGO Activist website communications. A second experimental group was exposed to these website communications in the reverse order. Given the extremely high exposure in the news media of the conflict arena surrounding this project, it was deemed necessary to compare these perceptions of the experimental groups with a control group representing a baseline for assessing any additional effects on perception due specifically to the respective Corporate and Activist NGOs website communications. 
RESEARCH DESIGN

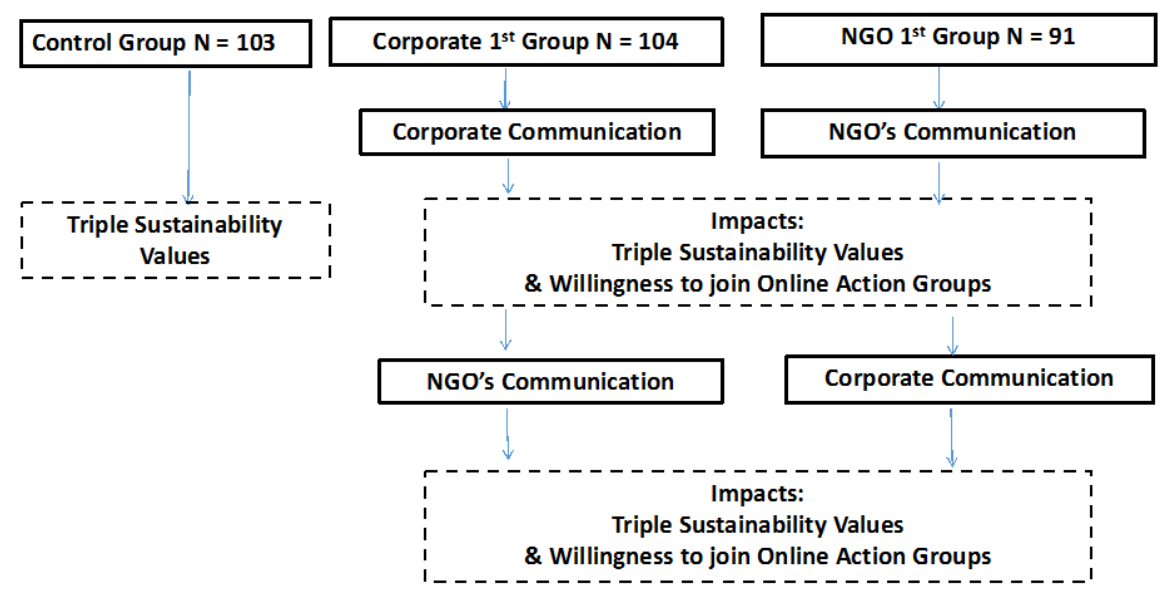

Figure 1. Experimental Research Design

\subsection{Theoretical Framework and Hypotheses}

1.2.1. Impacts of the framing of Corporate and Activist NGOs website communications on the perceptions of the tripartite sustainability values.

Considerable research using TBL shadow accounting and shadow reporting can demonstrate how NGOs can shed light on what some companies report and suppress about their sustainability initiatives (Tregigda, 2013). However, Dyllick and Muff (2016) propose a more advanced theoretical approach to studying the tripartite nature of corporate sustainability. They describe the evolution of business sustainability as moving from business as usual for shareholder value, to a three-dimensional concept of creating values for the common good. Clearly described by Alhaddi (2015), tripartite business sustainability is the creation of economic value for the organization and the surrounding system, the provision of social value through the interaction between the organization and the community, and the attainment of environmental value for future generations through engagement in practices that do not compromise environmental resources in the longer term. Therefore, in this study we redirect the three pillars of sustainability (Figge et al., 2002) from the accounting term of TBL to the broader term of Tripartite Sustainability Values (TSV). This redirection is also congruent with efforts to counteract the corporate hegemony over the concept of sustainability (Tregidga et al., 2015).

Website battles over issues such as oil spills are now as much to do with communication aimed at "winning hearts and minds' as they are to do with communicating science-based or expert evidence (Hansen, 2011). In their recent treatment of perception as a central concept of social research and media perception specifically,
McLeod, Wise and Perryman (2017) point out that "reality" is in the mind of the observer. As cited by Ragas and Kiousis (2010), Cohen (1963) observed that mass media may not tell the public "what to think' but it is stunningly successful in telling them "what to think about". At the time of data collection, none of the four controversial bituminous oil pipeline projects had gained national government approval in the United States or Canada. With subsequent changes of the political parties in the national governments, the Keystone XL and Kinder Morgan pipelines have been nationally approved although considerable activist opposition still exists at the state and provincial levels. The acknowledged persuasive power of website communications (Kassinis and Panayiotou, 2017) would tend to result in the desired effect of the TSV framing of either the corporate or Activist NGOs.

Therefore, we hypothesize that the perceptions of the tripartite sustainability values:

H1a: of participants exposed only to the Corporate website communication will be significantly higher than those of the control group.

H1b: of participants exposed only to the Activist NGOs website communication will be significantly lower than those of the control group.

It is also possible that these original perceptions could be modified with subsequent exposure to the opposing website communication. Both website communications framed their agenda messages to persuade an audience of citizens and politicians to be for or against the proposed pipeline. The Corporate website was basically communication of vague claims and images of nature and greenness, whereas the Activist NGO websites included a substantial quantity of more factual, realistic information.

Therefore, we hypothesize that the perceptions of the tripartite sustainability values: 
H1c: of participants first exposed to the Corporate website communication will become significantly lower after their subsequent exposure to the Activist NGOs website communication.

H1d: of participants first exposed to the Activist NGOs website communication will become significantly higher after their subsequent exposure to the Corporate website communication.

1.2.2. Impacts of TSV framing of Corporate and Activist NGOs website communications on the willingness to join their respective online action networks:

An increasingly important goal of an organization's website communication is to develop supportive social media networks that can enhance pertinent information transmission and lead to more widespread actions (Lovejoy and Saxton, 2012). Such networks engender new paradigms of public engagement because they are free, interactive and permit any for- or non- profit organization to create online communities of followers with whom they are in constant real-time contact (Lovejoy and Saxton, 2012). In general, Millennials are described as an "Empathic Generation" (Arnett, 2010), attentive and respectful, having a desire to make the world a better place by turning to social media to pool their resources and promote their favorite causes (Silverman, 2007). A majority are interested in participating in a non-profit group and becoming part of a community (The Millennial Impact, 2013). To gain Millennial's support for causes through social media, it is better to appeal mainly to the benefits others derive than to benefits to the self (Paulin et al., 2014). Millennials strongly value a company's social and environmental commitments and are not afraid of punishing irresponsible firms, by rejecting their products or services, refusing to work at that company, and/or encouraging family and friends to boycott that company (Cone Inc., 2006). Social identity theory (Tajfel and Turner, 1986) implies that group-based identity and a sense of community should increase social engagement because it increases one's sense of belonging (Ardèvol-Abreu et al., 2017; Schattke, Ferguson and Paulin, 2018). Thus, a population of Millennial business students might be more persuaded to engage in an Activist NGOs rather than a Corporate online action network.

Therefore, we hypothesize that:

H2a: after the first website exposures, the willingness to join the Activist NGOs online action network will be significantly greater than for that of the Corporate Energy East Pipeline.

$\mathrm{H} 2 \mathrm{~b}$ : after exposure to the two website communications, the willingness to join the online action network will be significantly greater for the Activist NGOs than for that of the Corporate Energy East.

\section{Method}

\subsection{Participants}

The participants were first-year undergraduate students from a Canadian university business school $(N=350$; Mean age 22 , range $17-30$ years; $53 \%$ Females; $47 \%$ Males). The majority were in their first semester of studies. This student population can register to participate in one research study on a third-party online platform. Students in core courses can gain an additional two percent of their grade by participating in a research project. No monetary or other incentive for participation is given. Historically, more than $65 \%$ of these students take part in one of the available research projects. The projects do not specifically reflect the content of the particular core courses. The titles of available projects are posted on the platform at the beginning of a semester. Students selecting to participate in the present study were only made aware of the very neutral or generic project title "Millennials, Social Media and Interactions between Business and Society". To avoid selection bias based on the particular research subject, no prior reference to oil sands pipelines, the environment, or corporate sustainability was given. None of the participants were students of the research investigators.

\subsection{Design and Procedures}

Individuals seeking information about this conflict arena of interaction between oil pipeline companies and Activist NGOs would normally google "Energy East Pipeline" where they could find pertinent information about the Energy East Pipeline from both the websites of the Trans Canada Corporation and an Activist NGO such as the Council of Canadians. Therefore, similar to Gauthier and Kappen (2016) we analyzed website content about TSV. First, one set of our researchers carefully scrutinized the corporate Energy East Pipeline website. The framing of this communication specifically addressed the corporate agenda with respect to the TSV outcomes presented in the following order: environmental safety, proposed economic benefits and community relationships with municipalities and First Nations. YouTube videos, images and texts from this website regarding these issues were then inserted into Qualtrics to be viewed as the "Corporate Communication". Second, another set of researchers scrutinized the website communications of Activist NGOs such as the Council of Canadians opposed to the Energy East Pipeline project for materials matching the same TSV as presented in the Corporate website. Again, pertinent communications of YouTube videos, images and texts were subsequently inserted into Qualtrics as the "Activist NGOs Communication".

Using Qualtrics, participants were exposed online to either neutral information (control group), or to the Corporate and Activist NGOs website communications regarding the proposed Energy East Pipeline (Figure 1). The control group $(\mathrm{N}=140)$ were only informed that this $4600 \mathrm{~km}$ pipeline would carry oil from Alberta to the Atlantic coast in eastern Canada. It would consist of converting a $3000 \mathrm{~km}$ existing natural gas pipeline to 
Ontario and a new $1600 \mathrm{~km}$ section through Ontario and Quebec to New Brunswick. They also viewed a map identifying this pipeline as one of three other proposed pipelines from Alberta to the Pacific coast and to Nebraska in the United States. The remaining 210 participants were randomly assigned to one of two experimental groups. The Corporate $1^{\text {st }}$ group first viewed the Energy East Pipeline Corporate Communication about the three sustainability values and secondly viewed these same issues in the Activist NGOs Communication. The Activist NGOs $1^{\text {st }}$ group viewed these communications in the reverse order. Note that the Corporate and Activist NGOs communications and assessment of perceptions of the material for the same tripartite sustainability values were viewed separately in their entirety. Participants were instructed to carefully examine the material and answer the questions for each sustainability value. This procedure permitted the researchers to reject 14 participants who did not comply with the instructions.

The control group's perceptions of the TSV concerning the Energy East Pipeline project were also assessed on Qualtrics. The perceptions of these values were assessed for both the Corporate $1^{\text {st }}(\mathrm{N}=104)$ and Activist NGOs $1^{\text {st }}$ $(\mathrm{N}=92)$ groups after viewing each of the Corporate and Activist NGO communications. Similarly, the participant's degree of willingness to join the Corporate or Activist NGOs community social media action networks was assessed after having viewed the respective communications.

\subsection{Measures}

All construct items were measured using seven-point Likert scales (see Appendix).

\subsubsection{Perceptions of Triple Sustainability Values}

The participants' perceptions were based on the Corporate and Activist NGOs website communications about the proposed Energy East Pipeline Project regarding Environmental Safety (4 items), Economic Benefits (2 items) and Community Relationships (2 items). Environmental Safety perceptions concerned: the degree to which the pipeline could be monitored effectively, the possibility of leaks in an older pipeline, immediate detection of failure and diluted bitumen being no different from crude oil. The Economic Benefits assessed the perception that many jobs would be created in Eastern Canada and that the pipeline oil was for Eastern refineries and domestic use. Community Relationships assessed the perception that a majority of Quebec municipalities support the pipeline and that relations with First Nations groups were frequent and very cordial.

\subsubsection{Willingness to Join the Energy East Pipeline Action Network Movement Online}

The perceptions of this 6-item construct included: learning more about the benefits of the project, share your story of how the project affects you, sign the petition in support of the pipeline, like, share videos, comment on pipeline on Facebook or Twitter, attend an Energy East open-house and, download and share the Energy East Virtual Tool Kit.

\subsubsection{Willingness to join the NGO Council of Canadians' Action Network Movement Online against the Energy East Pipeline}

The perceptions of this 6-item construct included: signing the Stop Energy East Pipeline petition, tell the National Energy Board a fair process is needed, share videos and pictures, comment on Council of Canadians' Facebook and Twitter, join and donate to the Council of Canadians and sign up to receive monthly updates on the Energy East Campaign.

\section{Results}

3.1. Impacts of framing Corporate and Activist NGOs website communications on the perceptions of the tripartite sustainability values:

A three-step analytic strategy was applied to test the separate impacts of the Corporate (H1a) and Activist NGOs (H1b) website communications on the participants' perceptions of the tripartite sustainability values of environmental safety, economic benefits and community relationships. The MANOVA and ANOVA results as well as the means and standard deviations are shown for the control and both experimental groups (Table 1).

First, Multivariate Analysis of Variance (MANOVA) was calculated in order to test for mean differences of the tripartite sustainability values as a whole. The advantage of this analysis is that it accounts for possible relationships among the tripartite sustainability values and that it controls for Type I error inflation (Field, 2009) in contrast to separate ANOVAs. The results indicated significant mean differences between the three conditions (Corporate $1^{\text {st }}$, Control, and Activist NGOs $1^{\text {st }}$ ) on some or all of the tripartite sustainability values (see Note in Table 1). Second, separate follow-up ANOVAs for each of the three sustainability values demonstrated significant mean differences between environmental safety, economic benefits, and community relationships. This permitted the investigation of the differences between specific groups in the next step. Third, planned simple contrasts between the Corporate $1^{\text {st }}$ and the Control condition as well as between the Control and the Activist $1^{\text {st }}$ condition for each of the tripartite sustainability values demonstrated that participants exposed only to the Corporate communication had significantly higher perceptions of environmental safety, $\mathrm{t}(187.22)=6.45, \mathrm{p}<.001, \mathrm{R}^{2}=.18$, economic benefits, $\mathrm{t}(199.22)=5.29, \mathrm{p}<.001, \mathrm{R}^{2}=.12$, and community relationships, $\mathrm{t}(332)=8.00, \mathrm{p}<.001, \mathrm{R}^{2}=.16$ ) than participants in the control condition. This supports Hypothesis 1a. Moreover, those exposed only to the Activist NGOs communication had significantly lower 
perceptions of environment safety, $\mathrm{t}(132.73)=-7.07, \mathrm{p}$ $=.001, \mathrm{R}^{2}=.27$, economic benefits, $\mathrm{t}(135.00)=-9.60, \mathrm{p}$ $<.001, \mathrm{R}^{2}=.41$, and community relations, $\mathrm{t}(332)=-11.37$, $\mathrm{p}<.001, \mathrm{R}^{2}=.28$ than participants in the control condition. This supports Hypothesis $1 \mathrm{~b}$.

These results indicate that both, the Corporate and the Activist NGOs website communications, achieved their respective agendas of influencing the perceptions of the target group of participants in this study. Interestingly, the differences between the Activist NGOs and the Control condition appear to be stronger than the differences between the Corporate and the Control condition, as indicated by the effect sizes $\left(\mathrm{R}^{2}\right)$.

Paired-sample T-Tests of the means (Table 2) were calculated to determine if subsequent viewing of the opposite communication websites resulted in a reversal of the original perceptions of the Corporate or Activist NGOs communication of the tripartite sustainability values (H1c and H1d). The results demonstrated that the TSV of participants first exposed to the Corporate website communication became lower after participants' subsequent exposure to the Activist NGOs website communication. This supports Hypotheses 1c. Also, the perceptions of the TSV of participants first exposed to the Activist NGOs website communication became higher after their subsequent exposure to the Corporate website communication. This supports Hypothesis 1d. Interestingly, the decrease of perception from the Corporate to the
Activist NGOs communication was larger (average effect size $\mathrm{R}^{2}=.66$ ) than the increase from the Activist NGOs to the Corporate communications (average effect size $\mathrm{R}^{2}$ $=.21$ ). One can conclude that exposure to the other communication had the effect of reversing the previous perception but the reversal was greater for participants first exposed to the Corporate website communication.

3.2. Impacts of framing Corporate and Activist NGOs website communications on the willingness to join their respective online action networks:

T-tests of means were calculated to determine if, after the first website exposures, the willingness to join the activist NGOs online action network was greater than for that of the Corporate Energy East (H2a). This hypothesis was supported given that the mean value $(\mathrm{M}=4.79, \mathrm{SD}=$ 1.10) for the willingness to join the Activist NGOs online action network was significantly greater than that $(\mathrm{M}=$ 4.05, $\mathrm{SD}=1.16)$ for the Corporate Energy East group $\left(\mathrm{t}(193)=-4.54, \mathrm{p}<.001, \mathrm{R}^{2}=.10\right)$. Similarly, T-test results also supported $\mathrm{H} 2 \mathrm{~b}$, where after exposure to the second website communications, the mean value for the willingness of the Activist NGOs $1^{\text {st }}$ group to join the Council of Canadians' online community network $(\mathrm{M}=$ $4.64, \mathrm{SD}=1.17)$ was again significantly greater than that of the Corporate $1^{\text {st }}$ group $(\mathrm{M}=3.36, \mathrm{SD}=1.29)$ to join the Energy East online community network $(\mathrm{t}(193)=7.24, \mathrm{p}$ $\left.<.001, \mathrm{R}^{2}=.21\right)($ Figure 2).

Table 1. Comparison of the Perceptions of Tripartite Sustainability Values between the Control and the Corporate and Activist NGOs Website Communications

\begin{tabular}{|c|c|c|c|c|}
\hline & Corporate $1^{\text {st }}$ & Control condition & Activist NGOs $1^{\text {st }}$ & ANOVA Results \\
\hline Tripartite Sustainability Values & Mean $(S D)$ & Mean $(S D)$ & Mean $(S D)$ & $F$-values, $d f \mathrm{~s}, p$-values, effect sizes \\
\hline Environmental Safety & $4.47(1.05)$ & $3.67(0.81)$ & $2.56(1.35)$ & $F(2,332)=79.84, p<.001, \eta^{2}=.33$ \\
\hline Economic Benefits & $5.24(1.02)$ & $4.59(0.86)$ & $3.02(1.39)$ & $F(2,332)=108.24, p<.001, \eta^{2}=.40$ \\
\hline Community Relationships & $4.75(1.21)$ & $3.60(1.05)$ & $1.90(1.05)$ & $F(2,332)=160.60, p<.001, \eta^{2}=.49$ \\
\hline
\end{tabular}

Note. MANOVA using Pillai's trace: $V=0.56, F(6,662)=42.69, p<.001, \eta^{2}=.28$.

Table 2. Comparison of the Perceptions of the Tripartite Sustainability Values for the $1^{\text {st }}$ and $2^{\text {nd }}$ Views of the Website Communications for the Corporate $1^{\text {st }}$ and Activist NGOs $1^{\text {st }}$ groups.

\begin{tabular}{|c|c|c|c|c|}
\hline & \multicolumn{2}{|c|}{ Corporate $1^{\text {st }}$ Group } & \multicolumn{2}{|c|}{ Activist NGOs $1^{\text {st }}$ Group } \\
\hline & Corporate & Activist NGOs & Activist NGOs & Corporate \\
\hline \multirow{2}{*}{$\begin{array}{l}\text { Tripartite } \\
\text { Values }\end{array}$} & Mean $(S D)$ & Mean $(S D)$ & Mean $(S D)$ & Mean $(S D)$ \\
\hline & \multicolumn{2}{|c|}{ Paired sample $t$-tests } & \multicolumn{2}{|c|}{ Paired sample $t$-tests } \\
\hline \multirow{2}{*}{ Environmental Safety } & $4.47(1.05)$ & $2.85(1.24)$ & $2.56(1.35)$ & $3.06(1.33)$ \\
\hline & \multicolumn{2}{|c|}{$t(103)=12.20, p<.001, R^{2}=.59$} & \multicolumn{2}{|c|}{$t(90)=-4.41, p<.001, R^{2}=.18$} \\
\hline \multirow{2}{*}{ Economic Benefits } & $5.24(1.02)$ & $3.24(1.46)$ & $3.02(1.39)$ & $3.74(1.47)$ \\
\hline & \multicolumn{2}{|c|}{$t(103)=14.23, p<.001, R^{2}=.66$} & \multicolumn{2}{|c|}{$t(90)=-5.87, p<.001, R^{2}=.28$} \\
\hline \multirow{2}{*}{ Community Relationships } & $4.75(1.21)$ & $2.08(1.12)$ & $1.90(1.08)$ & $2.53(1.32)$ \\
\hline & \multicolumn{2}{|c|}{$t(103)=18.55, p<.001, R^{2}=.77$} & \multicolumn{2}{|c|}{$t(90)=-5.73, p<.001, R^{2}=.27$} \\
\hline
\end{tabular}

Note. The effect size $R^{2}$ represents the percentage of variance explained by the differences. 


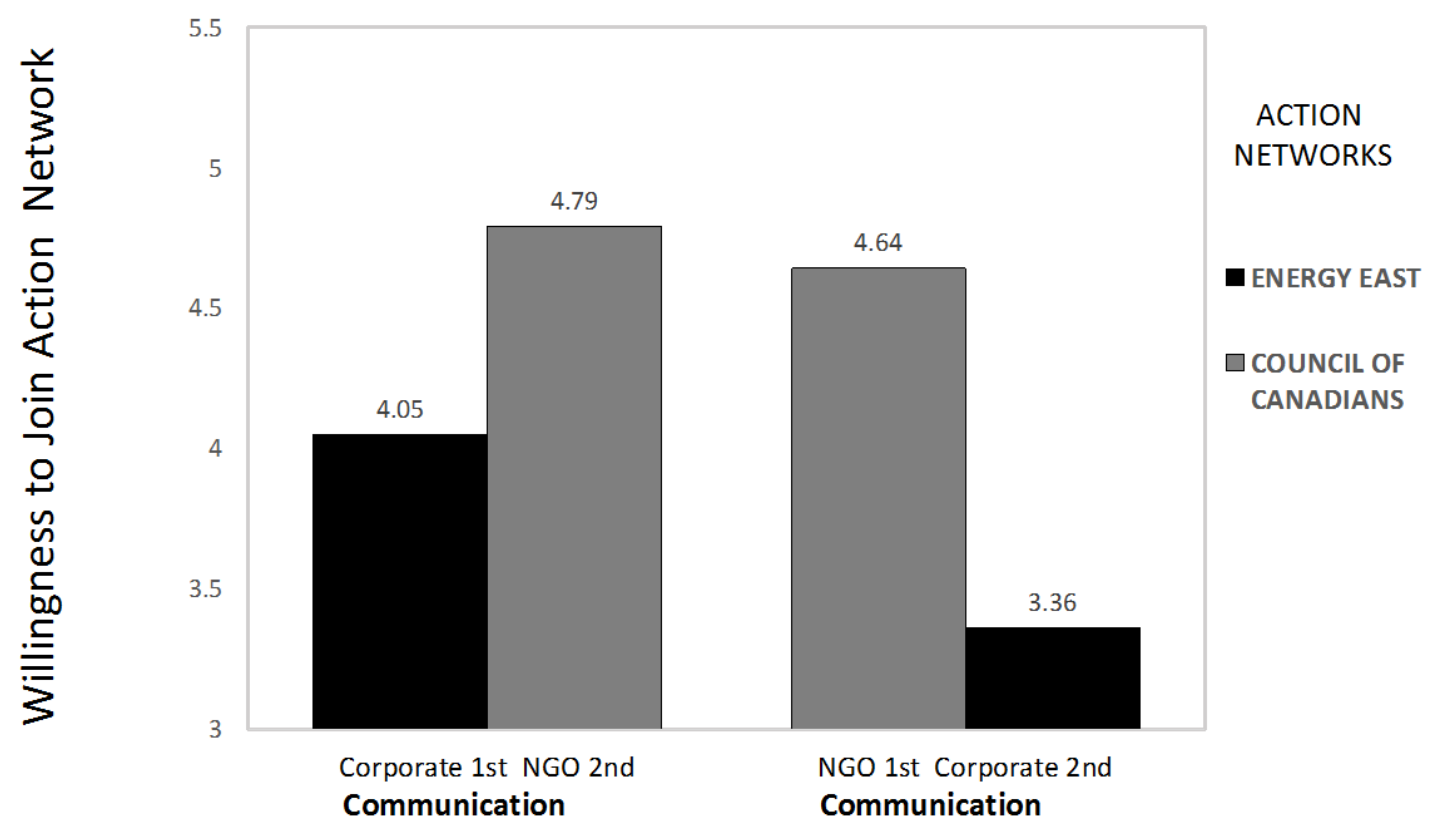

Figure 2. Effects of First and Second Exposures to the Corporate Energy East and NGOs Council of Canadians Website Communications on the Willingness to Join the Online Community Action Networks.

\section{Discussion}

\subsection{Summary of Empirical Findings}

Compared to a control group, the results of the experimental groups' exposures to the Corporate and Activist NGO online communications clearly demonstrated significantly different perceptions of the TSV issues. Whereas, both communications achieved their respective purposes of creating the desired participant perceptions (positive after the Corporate and negative after the Activist NGO communications), these were reversed after exposure to the opposite website communications. The corporate $1^{\text {st }}$ group's subsequent viewing of the Activist NGO communication resulted in a dramatic reduction of TSV perceptions from slightly positive to very negative. There was also a reversal of perceptions by the Activist $1^{\text {st }}$ group after their subsequent exposure to the Corporate communication, although they remained negative.

We also showed that exposure to these website communications affected the experimental groups participants' propensity to join online communities and act on social media (e.g. twitter, Facebook etc.). The willingness to join the activist NGO Council of Canadians online action network was greater compared to that of the corporate TransCanada Ltd. However, the order of the communication also affected the willingness of the Corporate $1^{\text {st }}$ group to join the corporate action network. Here, this willingness became significantly less upon subsequent exposure to the activist NGO network. It seems that having seen the Activist NGO view first resulted in fewer participants joining the Corporate action network.
The willingness to get involved in the Activist NGO action group was significantly greater than the corporate one no matter in what order the exposures. These results tend to support the argument that Millennials are more a "We" than a "Me" generation (Paulin et al., 2014).

The potential explanation for our research findings can be found by an in-depth comparison of the pro-versus-con claims evident in the corporate and Activist NGOs website communications.t whereas the Corporate website communication was basically framed as a multitude of opinions, the Activist NGOs websites presented a substantial quantity of factual and verifiable information. Some of the many examples of the conflicting Corporate versus Activist NGOs website sustainability claims were respectively a) environmental safety: with a pipeline failure diluted bitumen would not sink to the bottom of a river versus Enbridge pipeline failure at Kalamazoo Michigan in 2010 resulted in bitumen oil sinking to the bottom of the river, b) Economic Benefits: the pipeline will serve Eastern Canadian markets and create Canadian energy self-sufficiency versus TransCanada CEO Russ Girling states that this pipeline is for exporting the oil over water and c) Community relations: we have an aboriginal policy based on trust and respect versus 70 First Nations leaders are actively opposed to the pipeline.

\subsection{Theoretical Implications}

The framework of our research was mainly based on Dyllick and Muff's (2016) proposal for a more advanced theoretical approach to the study of the tripartite nature of corporate sustainability. In accordance with their Business Sustainability 3.0 concept, achieving truly sustainable 
business means shifting the notion of value creation from the triple bottom line accounting analogy of refined shareholder value, to creating values for the common good through all three-dimensional concerns (environmental, economic and social). The use of TSV is more pertinent than TBL for studying the corporate and stakeholder framing and assessment of the influence of media communication on the perceptions and attitudes of specific populations with regard to future products and projects. In the present study, both the TransCanada Ltd. and the activist NGOs employed this approach to framing their website communication about the proposed Energy East Pipeline Project. Our results demonstrating the differing corporate and activist NGO perspectives of TSV issues for the common good was pertinent and timely given that, although an increasing number of firms are claiming to manage sustainability, there is a need to distinguish those who do so from those that do not (Dyllic and Muff, 2016). However, one must not be naïve in ignoring the fact that behind these particular website framings of TSV were the corporate goal of achieving profit and shareholder wealth and that of the activists and stakeholders for this not occurring to the potential detriment of the environment and society.

\subsection{Practical Implications}

This research highlights the importance of research and teaching of sustainability in business schools, where it is important to challenge students to take a critical approach to current and future business practices informed by these issues (Eagle et al., 2015). The theoretical and practical implications of our findings in the context of sustainability in higher education is consistent with the call for academics to ramp up resistance to a corporate hegemony on sustainability where current academic endeavors on sustainability are more aligned with corporate systems reinforced by universities being not tolerant of "noisy muckrakers" (Tregidga et al., 2015, p.31). This situation also reflects the increasing corporatization of universities and business schools (Huzzard et al., 2017). Although business schools increasingly profess their engagement in sustainability values, many actually institutionally decouple their espoused commitments from what they practice (Snelson-Powell, Grisvold and Millington, 2016). The present findings can also have important implications for developing a more balanced and ethical business curriculum in the area of sustainability (Eagle et al., 2015). In particular, course content related to business sustainability and corporate social responsibility should include analyses of examples from both ethical and unethical sustainability communication and practices. Business students should become experts at recognizing the differences between truly sustainable practice and greenwashing.

Our empirical study is analogous to a one-time photograph of the Corporate/Activist NGOs website interaction in the conflict arena of bituminous oil pipelines. Kassinis and Panayiotou (2017) demonstrated the evolving nature of this type of conflict with the BP Corporate website communication used to counteract accusations of greenwashing following the DeepWater Horizon disaster. More studies are required to elucidate the "ongoing" interaction between both the Corporate, Activist NGOs and governmental website communications in the particular volatile political context of these proposed pipelines. Such volatility is evident by the recent preliminary approval in Nebraska of the TransCanada Keystone XL days after a major spill at the South Dakota section of the existing Keystone pipeline and, this same company's recent decision to withdraw their application for the Canadian National Energy Board approval of the Energy East Pipeline. More recently, after environmental concerns delaying the Trans Mountain Pipeline, the Canadian Government purchased this project from the Kinder Morgan Company.

\section{Acknowledgements}

This research is a pertinent activity within Dr. Paulin's Royal Bank of Canada Professorship in Strategic Relationship Marketing.

\section{Appendix (Questionnaire Scale Items)}

Triple Sustainability values

"To what extent do you Agree or Disagree with the following statements about the proposed Energy East Pipeline" ( $1=$ Strongly Disagree, $2=$ Somewhat Disagree, $3=$ Disagree, $4=$ Neither Agree nor Disagree, $5=$ Somewhat Agree, $6=$ Agree, $7=$ Strongly Agree)

Environmental Safety? $(\alpha=.84)$

- The safety of the proposed pipeline can be adequately monitored.

- The possibility of a pipeline leak is negligible.

- Any pipeline failure would be immediately detected and the consequences would be minimal.

- A pipeline leak of diluted bitumen would be no different from regular crude oil.

Economic Benefits? $(\alpha=.77)$

- Many permanent jobs will be created in Eastern Canada.

- Pipeline oil is destined mainly for Eastern Canada refineries for domestic use.

Community Relationships? $(\alpha=.86)$

- A majority of Quebec municipalities support the pipeline. 
- Relationships with aboriginals and First Nations are very cordial regarding the pipeline project.

Willingness to Join Online Action Networks

"How willing are you to join the TransCanada Energy East Pipeline ACTION NETWORK movement where you would:" (1=Highly Unwilling, 2=Somewhat Unwilling, $3=$ =nwilling, 4=Neither Unwilling nor Willing, $5=$ Somewhat Willing, $6=$ Willing, $7=$ Highly Willing) $(\alpha=.86)$

- Learn more about the benefits of this pipeline project.

- Share your own story about how the pipeline project affects you

- Sign the petition in support of the pipeline project.

- Like, share videos and picture and comment about the pipeline information on Facebook or Twitter.

- Attend an upcoming Energy East open house in my neighborhood.

- Download their Virtual Tool Kit with documentation to share with others.

"How willing are you to join the Council of Canadians' movement to TAKE ACTION against the Energy East Pipeline where you would:" (1=Highly Unwilling, 2=Somewhat Unwilling $3=$ Unwilling, $4=$ Neither Unwilling nor Willing, $5=$ Somewhat Willing, $6=$ Willing, $7=$ Highly Willing $)(\alpha=.95)$

- $\quad$ Sign the "Stop the Energy East Pipeline" petition.

- Tell the National Energy Board we need a fair pipeline review.

- Distribute copies of the poster Energy East "Our Risk. Their Rewards".

- Like, share videos and picture and comment about the Council of Canadians information on Facebook or Twitter.

- Join the Council of Canadian and donate to the Stop Energy East Campaign

- Sign up to receive monthly email updates on the Energy East campaign.

\section{REFERENCES}

[1] Alhadi, H. (2015). Triple bottom line and sustainability: A literature review. Business and Management Studies, 1, 6-10.

[2] Alves, I. (2009), "Green spin everywhere: How greenwashing reveals the limits of the CSR paradigm", Journal of Global Change and Governance, II, pp. 1-26.

[3] Ardèvol-Abreu, A., Barnidge, M. and Gil de Zúñiga, H. (2017), "Communicative Antecedents of Political Persuasion: Political Discussion, Citizen News Creation, and the Moderating Role of Strength of Partisanship", Mass Communication and Society, Vol. 20 No. 2, pp. 169-191.

[4] Arnett, J.J. (2010), Adolescence and Emerging Adulthood: A Cultural Approach, 4th ed., Prentice Hall, Boston, MA.
[5] Cherry, M.A. and Sneirson, J.F. (2012), "Chevron, greenwashing, and the myth of "Green Oil Companies", Washington and Lee Journal of Energy, Climate, and the Environment, Vol. 3 No. 1, pp. 133-154.

[6] Cone Inc. (2006), “The Millennial Generation: Pro-social and Empowered to Change the World", Retrieved from: http://blogthinkbig.com/wp-content/uploads/Cone-Millenn ial-Cause-Study-La-hora-de-cambiar-el-mundo.pdf.

[7] Cohen, B. (1963), The Press and Foreign Policy. Princeton, NJ: Princeton University Press.

[8] Coombs, W.T. and Holladay, S.J. (2018), "Social issue qua wicked problems. The role of strategic communication in social issues management", Journal of Communication Management, Vol. 22 No. 1, pp. 79-95.

[9] Delmas, M. and Aragon-Correa, J.A. (2016), "Field experiments in corporate sustainability research: Testing strategies for behavior change in markets and organizations", Organization \& Environment, Vol. 29 No. 4, pp. 391-400.

[10] Dyllick, T. and Muff, K. (2016), "Clarifying the meaning of sustainable business: Introducing a typology from business-as-usual to true business sustainability", Organization \& Environment, Vol. 29 No. 2, pp. 156-174.

[11] Eagle, L., Low, D., Case, P. and Vadommele, L. (2015), "Attitudes of undergraduate business students toward sustainability values", International Journal of Sustainability in Higher Education, Vol. 16 No. 5, pp. 650-668.

[12] Elkington, J. (1994), "Towards the sustainable corporation: Win-win-win business strategies for sustainable development", California Management Review, Vol. 36 No. 2, pp. 90-100.

[13] Field, A.P. (2009), Discovering Statistics Using SPSS: (3rd ed.). Los Angeles.

[14] Gauthier, J. and Kappen, J.A. (2016), "Corporate rhetorical strategies in the legitimation of genetically modified foods", Journal of Communication Management, Vol. 21 No. 3, pp. 218-235.

[15] Hahn, T., Figge, F., Aragón-Correa, J.A. and Sharma, S. (2017), "Advancing research on corporate sustainability: Off to pastures new or back to the roots?" Business \& Society, Vol. 56 No. 2, pp. 155-185.

[16] Hansen, A. (2011), "Communication, media, and environment: Towards reconnecting research on the production, content and social implications of environmental communications", International Communication Gazette, Vol. 73 No. 1-2, pp. 7-25.

[17] Huzzard, T., Benner, M.A and Kärreman, D. (2017), "Exploring and experiencing the corporate business school", In, The Corporatization of the Business School: Minerva Meets the Market. New York, Routledge.

[18] Jaques, T. (2006), "Activist "rules" and the convergence with issue management", Journal of Communication Management, Vol. 10 No. 4, pp. 407-420.

[19] Kagawa, F. (2007). "Dissonance in students' perceptions of sustainable development and sustainability", International Journal of Sustainability in Higher Education, Vol. 8 No. 3, 
pp. 317-338.

[20] Kassinis, G. and Panayiotou, A. (2017), "Visuality as greenwashing: The case of BP and Deepwater Horizon", Organization \& Environment, Vol. 31 No. 1, pp. 1-23.

[21] Lovejoy, K. and Saxton, G.D. (2012), "Information, community, and action: How nonprofit organizations use social media", Journal of Computer-Mediated Communication, Vol. 17(April), pp. 337-353.

[22] Lyon, T.P. and Montgomery, A.W. (2013), "Tweetjacked: The impact of social media on corporate Greenwash", Journal of Business Ethics, Vol. 118 No. 4, pp. 747-757.

[23] Mcleod, D.M., Wise, D., and Perryman, M. (2017), "Thinking about the media: A review of theory and research on media perceptions, media effects perceptions, and their consequences", Review of Communication Research, Vol. 5, pp. $35-83$.

[24] McQueen, D. (2015), "CSR and new battlelines in online PR war: A case study of the energy sector and its discontents", Developments in Corporate Governance and Responsibility. Vol. 7, pp. 99-125.

[25] Paulin, M., Ferguson, R.J., Jost, N. and Fallu, J.-M. (2014), "Motivating millennials to engage in charitable causes through social media", Journal of Service Management, Vol. 25 No. 3, pp. 334-348.

[26] Ragas, M.W. and Kiousis, S. (2010), "Intermedia agenda-setting and political activism: Moveon.org and the 2008 presidential election", Mass Communication \& Society, Vol. 13 No. 5, pp. 560-583.

[27] Schattke, K., Ferguson, R.J. and Paulin, M. (2018), "Motivations to support charity-linked events after exposure to Facebook appeals: Emotional cause identification and distinct self-determined regulations", Motivation Science, Vol. 4 No. 4, pp. 315-332.

[28] Silverman, R.E. (2007), “A new generation reinvents philanthropy: Blogs, social networking sites give 20 -somethings a means to push, fund favorite cause", The Wall Street Journal, August 21. Retrieved from: http://online.wsj.com/news/articles/SB1 187652563780034 94

[29] Smith, H., Suldofsky, B. and Lindenfeld, L. (2016), "Mass communication research in sustainability science: Moving toward an engaged approach to address society's sustainability dilemma", Mass Communication and Society, Vol 19 No. 5, pp. 548-565.

[30] Snelson-Powell, A., Grosvold, J. and Millington, A. (2016), "Business school legitimacy andthe challenge of sustainability: A fuzzy set analysis of institutional decoupling", Academy of Management Learning \& Education, Vol. 15 No. 4, pp. 703-723.

[31] Tajfel, H., and Turner, J.C. (1986), "The social identity theory of intergroup behavior", In S. Worchel \& W.G. Austin (Eds.), Psychology of Intergroup Relations (pp. 7-24). Chicago, Il: Nelson-Hall.

[32] Termeer, C.J., Dewulf, A., Breeman, G. and Stiller, S.J. (2013), "Governance capabilities for dealing wisely with wicked problems", Administration \& Society, Vol. 47 No. 6, pp. 680-710.
[33] The Millennial Impact (2013). "The Millennial Impact Research", Retrievedfrom:http:/www.themillennialimpact .com/2013Research.

[34] Tregidga, H. (2013), ““'Speaking truth to power”: Analyzing shadow reporting as a form of shadow accounting", Accounting Auditing \& accountability Journal, Vol. 30 No. 3, pp. 510-533.

[35] Tregidga, H., Milne, M.J. and Kearins, K. (2015), "Ramping up resistance: Corporate sustainable development and academic research", Business \& Society, Vol. 57 No. 2, pp. 292-334.

[36] Vaughter, P., McKenzie, M., Lidstone, L. and Wright, T. (2016), "Campus sustainability governance in Canada: A content analysis of post-secondary institutions' sustainability policies", Journal of Sustainability in Higher Education, Vol. 17 No.1, pp. 16-39. 